\title{
Geleneksel Gıda Ürünlerini Satın Alma Davranışları ve Tutumları: Mersin İli Örneği
}

\author{
Sinan Duru ${ }^{1 *}$ iD \\ Arzu Seçer ${ }^{2}$ iD \\ ${ }^{1}$ T.C. Ticaret Bakanlığı, Güney Anadolu Bölge Müdürlüğü, Mersin, Türkiye \\ ${ }^{2}$ Çukurova Üniversitesi, Ziraat Fakültesi, Tarım Ekonomisi Bölümü, Adana, Türkiye \\ (*Sorumlu yazar e-mail: s.duru85@ hotmail.com) \\ DOI: $10.17097 /$ ataunizfd.407116 \\ Geliş Tarihi (Received Date): 16.03.2018 \\ Kabul Tarihi (Accepted Date): 02.11.2018
}

\begin{abstract}
ÖZ: Türkiye'nin sahip olduğu coğrafi konum, iklim yapısı ve kültürel miras nedenleriyle geleneksel g1dalar önemli bir yere sahiptir. Bu çalışma, Mersin ili merkezinde geleneksel gıda ürünlerinde tüketicilerin satın alma davranışlarını ve tutumlarını ortaya koymak amacıyla yapılmıştır. Araştırmanın ana materyalini tüketicilerle yüz yüze görüşmeler sonucu elde edilen birincil veriler oluşturmaktadır. Anket sonucu elde edilen veriler frekans, oran ve ortalamalar hesaplanarak sunulmuştur. Araştırma bulgularına göre tüketiciler geleneksel gıda ile yöresel gıdanın aynı olmadığını düşünmektedir. Tüketiciler geleneksel gıda ürünlerini genellikle marketlerden satın almakta ve en çok süt ürünlerini tercih etmektedir. Tüketicilerin satın alma davranıșını en çok etkileyen unsurlar ise son kullanma tarihi, ürünlerin sağlıklı ve kaliteli olmasıdır. Ankete katılanların \%63.50'si paketlenmiş geleneksel ürünler için ek bir bedel ödeyeceklerini, bu kişilerin \%40.16'sı ise ürün fiyatının sadece \%1-5'i kadar ek bedel ödemeyi kabul edeceklerini ifade etmişlerdir.
\end{abstract}

Anahtar Kelimeler: Geleneksel Gıda, Tüketici Tercihleri, Tutum, Mersin, Türkiye

\section{Consumer's Purchase Behaviour and Attitudes In Traditional Food Products: Mersin Province}

\begin{abstract}
Turkey's has geographical position for reasons of climate structure and cultural heritage traditional foods has an important place. This study was carried out in Mersin Province to reveal consumers purchasing behaviors and attitudes towards traditional food products. The main material of the study is the primary data obtained by face to face interwievs with consumers. The data was analysied by calculating frequencies, ratios and averages. Consumers usually buy traditional food products from grocery stores and mostly prefer milk products. The most important factors affecting the purchasing behavior of the consumers are the expiration date, healthy and quality. $\% 63.50$ of survey participants explained that they would pay an additional price for packaged traditional foods, $\% 40.16$ of these participants said that would accept only an extra cost for \% $1-5$ of the product price.
\end{abstract}

Keywords: Traditional Food, Consumer Preferences, Attitude, Mersin, Turkey

\section{GİRIŞ}

Beslenme toplum açısından önemli bir unsur olup toplumsal beslenme, tarımın ülke ekonomisine sağladığı önemli katkılarından biridir. Türkiye'de tarımsal üretim çeşitliliği, iklim yapısı, coğrafi konum ve kültürel miras geleneksel gıdaların çeşitliliğini artırmaktadır. Ancak nüfusun artmasıyla gıda ürünlerine olan talep artmakta ve gida üretiminde teknoloji ön plana çıkmaktadır. Gıda üretiminde teknolojik gelişmeyle birlikte üretimde gıda katkı maddeleri kullanımı artışıyla geleneksel yöntemlerle üretilen gida sayısı azalmaktadır. Tüketicilerin geleneksel gıdaların daha sağlıklı ve doğal olduğu algısının artışıyla bu gıdalara talebin gün geçtikçe arttığı ifade edilmektedir.

Geleneksel gidalar, literatürde çeşitli şekillerde tanımlanmaktadır. Schneider ve Ceritoğlu (2010) geleneksel gıdayı coğrafi açıdan bir bölgeye veya yöreye özgü, kalitesini bölge veya yörenin doğal koşulları veya bilgi, deneyim ve geleneklerinden alarak üretiminde bölgenin hammadde ve üretim girdilerini kullanarak üretilen ürünler olarak ifade etmektedir. Balogh et al., (2016) bu gidalar1 gastronomik mirasa göre özel bir yöntemle hazırlanmış, duyusal mülkiyeti belli bir ülke, bölge veya yerel alanla ilişkilendirilmiş ürün olarak tanımlamaktadır. Cumhur'a (2017) göre geleneksel gıdalar özel kutlama veya dönemle ilişkilendirilen ve sürekli tüketilen, gastronomik mirasın bir parçası olup nesilden nesile aktarilan gidalar olup manipulasyon olmaksızın üretilerek duyusal özellikleriyle diğger gıdalardan ayrılan, belirli bir alan, bölge veya ülke ile ilişkilendirilen kendine has ürünler olarak tanımlanmaktadır. Dünya Gıda ve Tarım Örgütü tarafından kabul edilen tanıma göre ise "geleneksel gıda, kendine özgü özelliği veya özellikleri olan, benzer kategorideki ürünlerden birincil ürünlerin hammaddeleri veya geleneksel bileşim veya üretim metoduyla kolayca ayrılan g1dalardır" (Weichselbaum et al., 2009).

Türkiye'de geleneksel gidalarla ilgili mevzuat 5996 sayılı Veteriner Hizmetleri, Bitki Sağlığı, Gıda ve Yem Kanunu kapsamında Türk Gıda Kodeksi yönetmeliğiyle ortaya koyulmuştur. Türk Gıda Kodeksi yönetmeliğinde geleneksel gida, "Geleneksel hammaddeler kullanılarak üretilen veya geleneksel bir bileşim ya da geleneksel bir üretim biçimi ile tanımlanan veya doğrudan geleneksel bir üretim biçimine dayanmamakla birlikte, böyle bir üretim tarzını yansıtan işlemlerden geçirilmiş olması nedeniyle aynı kategorideki benzer ürünlerden açıkça 
ayrılabilen ürün” şeklinde tanımlanmaktadır (Anonim, 2011).

Son y1llarda dünyada ve Türkiye'de geleneksel gıda tüketim eğilimde artış gözlenmektedir (Onurlubaş ve Taşdan, 2017). Tüketiciler, bu ürünleri mikrobiyolojik tehlikelere karşı tamamen güvenli olmalarının yanı sıra az işlem görmüş olmaları, koruyucu madde içermemeleri, yüksek besin içeriğine sahip ve duyusal olarak değerli ürünler olmaları nedenleriyle talep etmektedir (Banterle and Gellynck, 2008). Bir ülkede kültür ve gelenek zenginliği tüketicinin arzu ettiği güvenli gıdayı daha az işlenmiş ve az katkı maddesi içerecek şekilde elde etmesine olanak sağlar (Kuşat, 2012). Türkiye'de de bu ürünlerin üretimi sırasında kullanımı yasaklanan gıda katkı maddeleri "Türk G1da Kodeksi Gıda Katkıları Maddeleri Yönetmeliği” kapsamında belirlenmiştir. $\mathrm{Bu}$ yönetmelik kapsamında fermante sucuk, 1sıl işlem görmüş sucuk, pastırma, döner, kanatlı döner, köfte, pekmez, çiğ köfte ile mezeler ve pide-bazlama gibi geleneksel gidalarda yasaklanan katkı maddeleri ayrıntılı olarak belirtilmiştir (Anonim, 2013).

Tüketicilerin geleneksel gıdaların diğer gıdalara göre daha sağlıklı olduğu algısı geleneksel gıdalara yönelik tüketim tercihini artırmaktadır. Tüketicilerin bu tutumu geleneksel gidaların ticari olarak pazarlanmasının önemini artırmıştır. Geleneksel gidaların ticari değerinin artması geleneksel gidalarla ilgili yasal düzenleme getirilme zorunluluğu gerektirmiş, bu amaçla 1995 yılında 555 sayılı "Coğrafi İşaretlerin Korunması Hakkında Kanun Hükmünde Kararname" yürürlüğe girmiştir (Anonim, 1995). Geleneksel gidalara yönelik yasal düzenlemeler ve tüketici bilinci artması geleneksel gıda satın alma davranış ve tutumuna yönelik çalışmaları zorunlu hale getirmiştir (Kadanalı ve Dağdemir, 2016).

Literatürde uluslararası düzeyde geleneksel gıdalarda tüketicilerin tercihlerini, tutumlarını ve satın alma davranışlarını ortaya koymaya yönelik çok sayıda çalışma bulunmaktadır (Balogh et al., 2016; Espejel et al., 2007; Almli et al., 2011; Cerjak et al,, 2014). Türkiye'de de bu konuyla ilgili yapılan çalışmalar mevcuttur. Schneider ve Ceritoğlu (2010) İstanbul ilinde yaptıkları çalışma sonucunda, yöresel ürün imajını "ürün özellikleri ve kalite", "markalama" ve "davranışsal" olarak üç boyutun ortaya çıkardığını, ayrıca tüketici satın alma davranışı ve yüksek fiyat ödeme eğilimi arasında anlamlı ilişki olduğunu belirlemişlerdir. Oraman vd. (2011) Tekirdağ ilinde yaptıkları çalışmada, tüketicilerin yoğurt, pekmez ve erişte gibi geleneksel ürünlerin tercihinde lezzet, gıda güvenliği ve tazelik gibi faktörlerin yanı sıra fiyatın da önemli düzeyde ve pozitif etkili olduğuna değinmişlerdir. Taşdan vd. (2014) Ankara ilinde geleneksel gidalarda tüketici algısını ve tercihlerini ölçmek amacıyla "Doğrusal Olmayan Kanonik Korelasyon" yönteminden yararlanarak tüketicileri demografik özelliklere göre 3'e ayırmış, 45 yaş ve üzeri kırsalla ilişkisi olan tüketici grubunun geleneksel gıda tüketiminde daha bilinçli olduğunu belirlemiştir. Karakaş ve Tönük (2016) geleneksel gıdaların 6-12 yaş arasındaki okul yaşındaki çocukların çocuk menülerinde, okul kantinlerinde ve öğrenci yemekhanelerinde bulunmasının sağlıklı bir beslenme alışkanlığı sağlayacağı ve geleneksel gıdaların tüketimini artıracağ1 üzerinde durmuştur. Başaran (2016) Trabzon ilinde geleneksel gidaların tüketiciler açısından tarih, kültür, miras, yöresel, özgün, doğal ve sağlık gibi anlamlara geldiğini ancak değerinin yeterince anlaşılamadığını ve bu değerin ortaya çıkarılması için daha çok çaba sarfedilmesi gerektiğini belirtmişlerdir. Kadanalı ve Dağdemir (2016) Erzurum ilinde tüketicilerin yöresel ürün satın alma istekliliğini demografik ve davranışsal olarak incelemiş ve kalite, fiyat ve tazeliğe yönelik beklentilerin markalaşma yoluyla olabileceğini tespit etmişlerdir. Onurlubaş ve Taşdan (2017) Türkiye'nin 7 coğrafi bölgesinin en büyük illerinde geleneksel ürün tüketimini etkileyen faktörleri araştırmış, geleneksel gıda algısının reklam ile geliştiğini ve gelir, besleyicilik ve aile bireylerin tüketici alışkanlığının etkisi gibi faktörlerin geleneksel gıda tüketimine olumlu etkisi olduğunu saptamışlardır.

Yapılan literatür çalışması sonucunda Mersin ilinde geleneksel gidalarda tüketicilerin tercihlerini ve satın alma davranışlarını etkileyen unsurları ortaya koyan bir çalışmaya rastlanmamıştır. Bu çalışmanın amacı, Mersin ilinde geleneksel gıda ürünlerinde tüketicilerin tercihlerinin (satın alınan ürünler, satın alma yeri, satın alma sıklığı vb), tutumlarının ve satın alma davranışını etkileyen unsurların ortaya koyulmasıdır.

\section{MATERYAL VE METOT}

\section{Materyal}

Araştırmanın ana materyalini Mersin ili merkezinde (Akdeniz, Toroslar, Yenişehir, Mezitli ve merkeze yakın olan Erdemli ilçelerinde) tüketicilerle yapılan anketler sonucu elde edilen birincil veriler oluşturmaktadır. Ankete katılan tüketicilerin, anakitleyi yeterince temsil edebilmesi için farklı yaş, eğitim, meslek ve gelir gruplarından seçilmesine özen gösterilmiştir.

Çalışmada kullanılan anket formu bu konuyla ile ilgili yapılmış önceki çalışmalar incelenerek ve uzman görüşü alınarak hazırlanmıştır (Onurlubaş ve Taşdan, 2017; Oraman vd., 2011; Taşdan vd., 2014; Başaran, 2016; Kadanalı ve Dağdemir, 2016; Koç vd., 2012). Anket formu 3 bölümden oluşmaktadır. Birinci bölümde tüketicilerin sosyo-demografik özelliklerini (yaş, eğitim, cinsiyet, meslek, aile 
büyüklüğü vb); ikinci bölümde tüketici tercihlerini (satın alınan ürünler, satın alma sıklığı, satın alma nedenleri vb.); üçüncü bölümde ise tüketicilerin geleneksel gıdalara yönelik tutumlarını ve satın alma davranışlarını etkileyen unsurları ortaya koymaya yönelik sorular sorulmuştur. Anketler 2016 yılının Kasım ve Aralık ayları arasında yapılmıştır.

\section{Metot}

Çalışmanın ana kitlesini Mersin ilinin merkezinde ve merkeze yakın olduğu için çalışma kapsamına alınan Erdemli ilçesinde ikamet eden 18 yaşın üzerinde 881.038 kişi oluşturmaktadır (Anonim, 2016). Araştırmaya konu olacak örneklem hacmi "Anakütle Oranlarına Dayalı Basit Tesadüfi Olasılık Örneklemesi” yöntemiyle hesaplanmıştır (Malhotra, 2004).

$$
\mathrm{n}=(\mathrm{z})^{2} \frac{(\mathrm{p} * \mathrm{q})}{\mathrm{d}^{2}}
$$

Formülde; n: Örnek büyüklüğü

z: 1.96 (\%95 güven düzeyine karşıl1k gelen standart z-degeri),

p: Anakütle oranı (örnek büyüklüğünün yüksek olması için 0.50 alınmıştır)

q: Olayın gerçekleşmeme olasılığı (örnek büyüklüğünün en yüksek değeri sağlaması için 0.5 alınmıştır)

d: Örneklem hata oranı (Çalışmada $\pm \% 5$ olarak kabul edilmiştir)

$$
\mathrm{n}=(1.96)^{2} \frac{(0.5 * 0.5)}{0.05^{2}}=384
$$

Örnek büyüklüğü \%95 güven aralığında ve $\% 5$ örneklem hata payı ile 384 olarak hesaplanmıştır. Tüketicilerin \%39.10'u Yenişehir, \%27.60'1 Mezitli, \%20.10'u Akdeniz, \%10.20'si Toroslar ve \%3.10'u Erdemli ilçesinde ikamet etmektedir (Çizelge 1).

Alan çalışması sonucu elde edilen veriler frekans, oran ve ortalamalar hesaplanarak sunulmuştur.
Çizelge 1. Ankete katılan tüketicilerin ikamet ettiği ilçelere göre dağılımı

\begin{tabular}{|l|c|c|}
\hline İkametgah & $\mathrm{n}$ & $\%$ \\
\hline Yenişehir & 150 & 39.10 \\
\hline Mezitli & 106 & 27.60 \\
\hline Akdeniz & 77 & 20.10 \\
\hline Toroslar & 39 & 10.20 \\
\hline Erdemli & 12 & 3.10 \\
\hline Toplam & 384 & 100 \\
\hline
\end{tabular}

\section{BULGULAR VE TARTIŞMA}

Tüketicilerin sosyo-demografik özellikleri

Ankete katılan tüketicilerin sosyo-demografik özellikleri Çizelge 2'de verilmiştir. Ankete katılan tüketicilerin \%52.90'1 kadın, \%36.20'si 40-54 yaşları arasında ve $\% 48.70$ 'i üniversite mezunudur. Tüketicilerin \%59.80'i memur ve işçilerden oluşmakta olup hane halkı büyüklüğü ortalama 3.53'dür. Görüşülen kişilerin ortalama aylık geliri 1818.00 TL iken gida harcaması ise 524.00 TL'dir.

Tüketicilerin geleneksel gıdalarla ilgili bilgi düzeyleri ve tüketim tercihleri

Geleneksel ürün ve yöresel ürün ifadeleri birçok kaynakta aynı anlamda kullanılmaktadır. Ancak, geleneksel üründen farklı olarak yöresel ürünler, "değişik bölgelerimizde üretilen ve üretildiği yöreye has tat, aroma ve bileşim gibi özelliklere sahip olan ürünler" olarak tanımlanmaktadır (Tan, 2009). Bununla beraber, Türk Patent ve Marka Kurumunca belli bir yöreye ait bazı ürünlerin gelenekselliği tescillenmeye başlanmış ve böylece yöresel ürünler geleneksel ürün özelliği taşımaya başlamıştır. $\mathrm{Bu}$ bakımdan geleneksel ürünler ve yöresel ürünler kavramlarının içiçe geçtiği söylenebilir. Araştırma alanında tüketicilerin \%24.00'1 geleneksel ürün ile yöresel ürünün aynı olduğunu, \%64.00'1 bu kavramların farklı ürün gruplarını tanımladığını ifade etmiştir. Ankete katılanların \%12.00'ının ise bu konuyla ilgili fikri bulunmamaktadır. 
Çizelge 2. Tüketicilerin sosyo-demografik özelliklerine göre dağılımı

\begin{tabular}{|c|c|c|c|c|c|}
\hline Cinsiyet & n & $\%$ & Medeni Durum & $\mathbf{n}$ & $\%$ \\
\hline Erkek & 181 & 47.10 & Evli & 228 & 59.40 \\
\hline Kadın & 203 & 52.90 & Bekar & 156 & 40.60 \\
\hline Toplam & 384 & 100.00 & Toplam & 384 & 100.00 \\
\hline Yaş & $\mathbf{n}$ & $\%$ & Aile Büyüklüğüu & $\mathbf{n}$ & $\%$ \\
\hline $18-25$ & 54 & 14.10 & 1 & 52 & 13.50 \\
\hline $26-39$ & 126 & 32.80 & 2 & 60 & 15.60 \\
\hline $40-54$ & 139 & 36.20 & 3 & 76 & 19.80 \\
\hline 55 ve üstü & 65 & 16.90 & 4 ve üstü & 196 & 51.10 \\
\hline Toplam & 384 & 100.00 & Toplam & 384 & 100.00 \\
\hline Ortalama & \multicolumn{2}{|c|}{41.28} & Ortalama & \multicolumn{2}{|c|}{3.53} \\
\hline Eğitim Durumu & $\mathbf{n}$ & $\%$ & Gelir (TL/ay) & $\mathbf{n}$ & $\%$ \\
\hline Okur-yazar & 24 & 6.20 & $<1404 *$ & 46 & 11.98 \\
\hline İlkokul & 46 & 12.00 & 1404-2999 & 167 & 43.49 \\
\hline Ortaokul & 44 & 11.50 & $3000-4499$ & 118 & 30.73 \\
\hline Lise & 83 & 21.60 & $4500+$ & 53 & 13.80 \\
\hline Yüksekokul & 19 & 4.90 & Toplam & 384 & 100.00 \\
\hline Lisans & 106 & 27.60 & Ortalama & \multicolumn{2}{|c|}{1818.00} \\
\hline Lisansüstü & 62 & 16.20 & Gıda Harcaması (TL/ay) & $\mathbf{n}$ & $\%$ \\
\hline Toplam & 384 & 100.00 & $<499$ & 120 & 31.25 \\
\hline Meslek & $\mathbf{n}$ & $\%$ & 500-999 & 149 & 38.80 \\
\hline Memur & 127 & 42.20 & 1000-1499 & 70 & 18.23 \\
\hline İşçi & 53 & 17.60 & $1500+$ & 45 & 11.72 \\
\hline Özel Sektör & 88 & 29.20 & Toplam & 384 & 100.00 \\
\hline Emekli & 33 & 11.00 & Ortalama & \multicolumn{2}{|c|}{524.00} \\
\hline Toplam** & 301 & 100.00 & $\begin{array}{c}\text { Mersin'de İkamet Süresi } \\
\text { (Ort.) }\end{array}$ & \multicolumn{2}{|c|}{20.00} \\
\hline
\end{tabular}

* Asgari Ücret Miktarı Esas Alınmıştır.

** Gelir getirici faaliyet olmadığı için evhanımları (48 kişi) ve öğrenciler (35 kişi) değerlendirmeye alınmamıştır.

Tüketicilerin, geleneksel ürün kavramını duyduklarında akıllarına gelen ürünler belirli ürün gruplarında yoğunlaşmamasına rağmen en sik ifade edilen ürünler yoğurt, peynir ve salça gibi evde hazırlanabilen ürünler olmuștur. Bu ürünler sırasıyla yoğurt (\%9.80), peynir (\%8.00), salça (\%4.70) ve pastırma (\%4.40)'dır (Çizelge 3). Oraman vd. (2011) lezzetli, güvenilir gıda ve taze olması açısından geleneksel gıda olarak evde yapılabilen yoğurt, erişte ve pekmezin önemli rol oynadığını belirtmişlerdir.
Ankete katılan tüketicilerin \%46.10'u bazen, $\% 27.10$ 'u sik sik, \%6.50'si her zaman, \%20.40'1 nadiren geleneksel gida satın almayı tercih etmektedir. Tüketicilerin \%28.90'1 geleneksel gida satın almada ilk tercihinin marketler olduğunu belirtmiştir (Çizelge 4). Taşdan vd. (2014) benzer bir çalışmada tüketicilerin en önemli gıda satın alma yerini market olarak belirlemiştir. Marketlerin geleneksel ürünler için ayrı raf ve stand oluşturmaları tüketicilerin geleneksel gıda satın almada market tercihini artırmaktadır. 
Çizelge 3. Tüketicilerin geleneksel gıdalara örnek olarak söyledikleri ürünler

\begin{tabular}{|l|c|c|}
\hline \multicolumn{1}{|c|}{ Ürünler } & $\mathrm{n}$ & $\%$ \\
\hline Yoğurt & 42 & 9.80 \\
\hline Peynir & 34 & 8.00 \\
\hline Salça & 20 & 4.70 \\
\hline Pastırma & 19 & 4.40 \\
\hline Yöresel ürünler & 18 & 4.20 \\
\hline Tarhana & 17 & 4.00 \\
\hline Sucuk & 15 & 3.50 \\
\hline Süt & 14 & 3.30 \\
\hline Pekmez & 13 & 3.10 \\
\hline Reçel & 12 & 2.80 \\
\hline Kayls1 & 11 & 2.60 \\
\hline Lokum & 10 & 2.30 \\
\hline Turšu & 10 & 2.30 \\
\hline Diğer & 192 & 45.00 \\
\hline Toplam & $427^{*}$ & 100.00 \\
\hline
\end{tabular}

*Birden fazla cevap verilmiştir.

Çizelge 4. Tüketicilerin geleneksel gıdaları temin etme yerleri tercih sıralaması

\begin{tabular}{|l|c|c|c|c|}
\hline \multirow{2}{*}{ Temin Şekli } & & 1. Tercih & 2. Tercih & 3. Tercih \\
\cline { 2 - 5 } Marketler & $\mathrm{n}$ & 111 & 47 & 31 \\
\hline \multirow{2}{*}{ Kendim Yapıyorum } & $\mathrm{n}$ & 28.90 & 12.20 & 8.10 \\
\cline { 2 - 5 } & $\%$ & 52 & 26 & 31 \\
\hline \multirow{2}{*}{ Memleketimden Temin Ediyorum } & $\mathrm{n}$ & 73.50 & 6.80 & 8.10 \\
\cline { 2 - 5 } & $\%$ & 19.50 & 62 & 61 \\
\hline \multirow{2}{*}{ Semt Pazarları } & $\mathrm{n}$ & 63 & 16.10 & 15.90 \\
\cline { 2 - 5 } & $\%$ & 16.40 & 24.70 & 73 \\
\hline \multirow{2}{*}{ Tanıdıklar Vasıtasıyla } & $\mathrm{n}$ & 41 & 85 & 76 \\
\hline \multirow{2}{*}{ Üretici } & $\%$ & 10.70 & 22.10 & 19.80 \\
\hline \multirow{2}{*}{ Tanıdıklar Vasitasiyla } & $\mathrm{n}$ & 42 & 57 & 86 \\
\cline { 2 - 5 } & $\mathrm{n}$ & 10.90 & 14.80 & 22.40 \\
\cline { 2 - 5 } Cevap Vermeyen & $\%$ & 41 & 85 & 76 \\
\cline { 2 - 5 } & $\mathrm{n}$ & 0.70 & 22.10 & 19.80 \\
\cline { 2 - 5 } & $\%$ & 0.00 & 12 & 26 \\
\hline
\end{tabular}

Tüketicilerin geleneksel gıdaları satın alma yerlerini tercih nedenlerini öncelik sırasına göre değerlendirmeleri istenmiştir. $\mathrm{Bu}$ durumda, tüketicilerin, $\% 34.10$ 'u güvenilir olmas1, $\% 19.80$ 'i alışkanlık, \%18.80'i ürün özelliğinin istediği gibi olmas1, \%11.20'si bütçeme uygun olmas1, \%9.60'1 satın aldığım yerin evime yakın olması, \%6.50'si ise satın aldığı kişinin tanıdık olmasının temin yeri tercihinin öncelikli nedeni olarak belirtmiștir (Çizelge 5). Bunun yanında tercih nedenleri ortalaması hesaplanmış olup, ortalaması en düşük çıkan satın aldığım yerin evime yakın olması ve güvenilir olması öncelikle tercih edilen unsurlar olarak sıralanabilir. 
Çizelge 5. Tüketicilerin geleneksel gıdaları temin etmede öncelikli tercih nedenleri

\begin{tabular}{|l|c|c|c|c|}
\hline \multicolumn{1}{|c|}{ Temin Şekli } & & 1. Tercih & 2. Tercih & 3.Tercih \\
\hline \multirow{2}{*}{ Satın Aldığım Yerin Evime Yakın Olması } & $\mathrm{n}$ & 37 & 45 & 28 \\
\cline { 2 - 5 } & $\%$ & 9.60 & 12.16 & 7.30 \\
\hline \multirow{2}{*}{ Güvenilir Olması } & $\mathrm{n}$ & 131 & 107 & 59 \\
\cline { 2 - 5 } & $\%$ & 34.10 & 28.91 & 15.40 \\
\hline \multirow{2}{*}{ Alışkanlık } & $\mathrm{n}$ & 76 & 29 & 50 \\
\hline \multirow{2}{*}{ Ürün Özelliklerinin İstediğim Gibi Olması } & $\mathrm{n}$ & 19.80 & 7.83 & 13.00 \\
\cline { 2 - 5 } & $\%$ & 72 & 90 & 56 \\
\hline \multirow{2}{*}{ Bütçeme Uygun Olması } & $\mathrm{n}$ & 48.80 & 24.32 & 14.60 \\
\hline \multirow{2}{*}{ Satın Aldı̆̆ım Kişinin Tanıdık Olması } & $\%$ & 11.20 & 15.41 & 69 \\
\cline { 2 - 5 } & $\%$ & 25 & 42 & 96 \\
\cline { 2 - 5 } & $\%$ & 6.50 & 11.35 & 25.00 \\
\hline
\end{tabular}

Tüketicilerin en çok satın aldıkları geleneksel gıdalar süt ürünleri $(\% 65.00)$, hayvansal ürünler (\%12.30), konserve ürünleri $(\% 8.60)$, kuru gıdalar (\%7.80) ve unlu mamullerdir (\%6.00) (Çizelge 6). $\mathrm{Bu}$ kișilerin en fazla satın aldıkları ürünler (geleneksel ürünlerin süt, hayvansal ve konserve ürünleri) ile geleneksel gıdalara örnek olarak söyledikleri ürünler (yoğurt, peynir, salça ve pastırma) birbirine benzemekte olup, bu sorulara verilen cevaplar birbirini doğrular niteliktedir. Kadanalı ve Dağdemir' de (2016) benzer bir çalıșmada tüketicilerin (3/4'ünün) en fazla satın aldığı ürünün peynir olduğunu belirlemiştir.

Çizelge 6. Tüketicilerin en çok tercih ettiği geleneksel gıdalar

\begin{tabular}{|l|c|c|c|c|}
\hline \multicolumn{1}{|c|}{ Temin Şekli } & & 1. Tercih & 2.Tercih & 3.Tercih \\
\hline \multirow{2}{*}{ Süt Ürünleri (peynir, yoğurt) } & $\mathrm{n}$ & 249 & 71 & 32 \\
\cline { 2 - 5 } & $\%$ & 65.00 & 18.50 & 8.30 \\
\hline \multirow{2}{*}{ Hayvansal Ürünler (sucuk, pastırma vb.) } & $\mathrm{n}$ & 47 & 115 & 82 \\
\cline { 2 - 5 } & $\%$ & 12.30 & 29.90 & 21.40 \\
\hline \multirow{2}{*}{ Unlu Mamuller } & $\mathrm{n}$ & 23 & 36 & 56 \\
\hline \multirow{2}{*}{ Konserve Ürünleri (Reçel, Sebze ) } & $\mathrm{n}$ & 6.00 & 9.40 & 14.60 \\
\cline { 2 - 5 } & $\%$ & 83 & 52 & 84 \\
\hline \multirow{2}{*}{ Kuru Gidalar (Kayıs1, İncir, Biber) } & $\mathrm{n}$ & 30 & 13.50 & 21.90 \\
\cline { 2 - 5 } & $\%$ & 7.80 & 25.30 & 27.90 \\
\hline
\end{tabular}

Tüketiciler gıda ve geleneksel gıdaları tercih şekillerine ilişkin ilgili bilgiler Çizelge 7'de verilmiştir. Ankete katılan tüketicilerin yarısından fazlas1 $(\% 54.40)$ geleneksel gidalar1 evde yapabildiğini, \%75.30’u ise özel günlerde geleneksel gıda tüketiminin arttığını belirtmişlerdir. Aktaş ve Yılmaz (2012) Mersin ilinde yaptığı çalışmada özellikle Ramazan ayında geleneksel ürün olan pide, hurma gibi geleneksel ürünlere olan talebin arttığını saptamıştır.

Çizelge 7. Tüketicilerin geleneksel gıdaları tercih şekilleri

\begin{tabular}{|l|c|c|c|c|}
\hline & & Evet & Hayır & Toplam \\
\hline \multirow{2}{*}{ Geleneksel gidaları evde yapabiliyor musunuz? } & $\mathrm{n}$ & 209 & 175 & 384 \\
\cline { 2 - 5 } & $\%$ & 54.40 & 45.60 & 100 \\
\hline \multirow{2}{*}{ Özel günlerde geleneksel gida tüketiminiz artıyor mu? } & $\mathrm{n}$ & 289 & 95 & 384 \\
\cline { 2 - 5 } & $\%$ & 75.30 & 24.60 & 100 \\
\hline
\end{tabular}




\section{Tüketicilerin geleneksel gıdalara karşı} tutumları

Tüketicilerin geleneksel gıdalara yönelik tutumlarını ortaya koymak amacıyla, tüketicilere 8 önermeden oluşan bir Likert ölçeği sunulmuş ve önermelere katılma düzeyleri belirlenmiştir. Tüketiciler, büyük oranda geleneksel gıdaların diğer gıdalara göre daha doğal (ort:4.26), daha lezzetli (ort:4.14), daha sağlıklı (ort:4.11) ve daha güvenilir (ort:3.91) olduğunu düşünmektedir. Bu kişiler aynı zamanda geleneksel gıdaların daha düşük kalorili (ort:3.00) ve daha ucuz (ort:2:84) olduğu görüşlerine ise daha az oranda katılmışlardır (Çizelge 8).

Çizelge 8. Tüketicilerin geleneksel gıdalara yönelik tutumları

\begin{tabular}{|c|c|c|c|c|c|c|c|c|}
\hline Unsurlar & & $1 *$ & 2 & 3 & 4 & 5 & Toplam & Ortalama \\
\hline \multirow{2}{*}{ Geleneksel gidalar daha doğaldır } & $\mathrm{n}$ & 18 & 6 & 37 & 122 & 201 & 384 & \multirow{2}{*}{4.26} \\
\hline & $\%$ & 4.70 & 1.60 & 9.60 & 31.80 & 52.30 & 100 & \\
\hline \multirow{2}{*}{ Geleneksel gidalar daha lezzetlidir } & $\mathrm{n}$ & 12 & 12 & 60 & 128 & 172 & 384 & \multirow{2}{*}{4.14} \\
\hline & $\%$ & 3.10 & 3.10 & 15.60 & 33.30 & 44.80 & 100 & \\
\hline \multirow{2}{*}{ Geleneksel gidalar daha sağlıklıdır } & $\mathrm{n}$ & 16 & 12 & 71 & 111 & 174 & 384 & \multirow{2}{*}{4.11} \\
\hline & $\%$ & 4.20 & 3.10 & 18.50 & 28.90 & 45.30 & 100 & \\
\hline \multirow{2}{*}{ Geleneksel gidalar daha güvenilirdir } & $\mathrm{n}$ & 14 & 20 & 89 & 126 & 135 & 384 & \multirow{2}{*}{3.91} \\
\hline & $\%$ & 3.60 & 5.20 & 23.20 & 32.80 & 35.20 & 100 & \\
\hline \multirow{2}{*}{ Geleneksel gidalar daha hijyeniktir } & $\mathrm{n}$ & 19 & 44 & 122 & 108 & 91 & 384 & \multirow{2}{*}{3.54} \\
\hline & $\%$ & 4.90 & 11.50 & 31.80 & 28.10 & 23.70 & 100 & \\
\hline \multirow{2}{*}{$\begin{array}{l}\text { Geleneksel gidalar daha kolay temin } \\
\text { edilir }\end{array}$} & $\mathrm{n}$ & 40 & 67 & 145 & 69 & 63 & 384 & \multirow{2}{*}{3.13} \\
\hline & $\%$ & 10.40 & 17.40 & 37.80 & 18.00 & 16.40 & 100 & \\
\hline \multirow{2}{*}{$\begin{array}{l}\text { Geleneksel gidalar daha düşük } \\
\text { kalorilidir }\end{array}$} & $\mathrm{n}$ & 62 & 74 & 109 & 77 & 62 & 384 & \multirow{2}{*}{3.00} \\
\hline & $\%$ & 16.10 & 19.30 & 28.40 & 20.10 & 16.10 & 100 & \\
\hline \multirow{2}{*}{ Geleneksel gidalar daha ucuzdur } & $\mathrm{n}$ & 60 & 97 & 117 & 63 & 47 & 384 & \multirow{2}{*}{2.84} \\
\hline & $\%$ & 15.60 & 25.30 & 30.50 & 16.40 & 12.20 & 100 & \\
\hline
\end{tabular}

*(1: Kesinlikle katılmıyorum, 2: Katılmıyorum, 3. Fikrim yok, 4: Katılıyorum, 5: Kesinlikle katılıyorum)

G1da ürünlerin paketlenmesinin amacı koruyucu olması, bilgi vermesi, satışı artırma, dikkat çekme, yenilik firsatı ve tüketici gönencidir (Örücü ve Tavşancı 2001). AB'ye uyum çalışmaları kapsamında geleneksel ürünlerin paketlenmesi gerekliliği vurgulanmaktadır. Bu kapsamda sektörde bir takım iyileştirmelerin yaşanması ve tüketicilerin bu yeni düzenlemelere uyum sağlanması beklenmektedir. Araştırma alanında tüketicilere geleneksel gidaları satın alırken paketli gidalara daha fazla fiyat ödemeye razı olup olmadikları sorulmuştur. Tüketicilerin \%63.50'si geleneksel gidaları paketli olarak satın alırken daha fazla fiyat ödemeyi kabul edebileceğini, geriye kalan \%36.50'si $(n=140)$ böyle bir durumda ek bir bedel ödemeyi kabul etmediğini ifade etmiştir. Geleneksel gıda satın alırken daha fazla fiyat ödemeye razı olan tüketicilerin \%40.16's1 \%1-5 daha fazla fiyat ödemeye razı olurken, \%31 ve üzeri fiyat vermeye razı olanların oranı \%6.56 olmuştur (Çizelge 9). Ayrica tüketicilerin $\% 68.20$ 'si ise gelirinin artmasıyla geleneksel gida tüketiminin artacağını belirtmiştir.
Çizelge 9. Tüketicilerin paketli ürün almak için ek olarak ödemeyi kabul ettikleri fiyatlar

\begin{tabular}{|l|c|c|}
\hline Ek Ödeme & $\mathrm{n}$ & $\%$ \\
\hline$\% 1-5$ & 98 & 40.16 \\
\hline$\% 6-10$ & 74 & 30.33 \\
\hline$\% 11-15$ & 33 & 13.52 \\
\hline$\% 16-20$ & 9 & 3.69 \\
\hline$\% 21-25$ & 9 & 3.69 \\
\hline$\% 26-30$ & 5 & 2.05 \\
\hline$\% 31$ ve üzeri & 16 & 6.56 \\
\hline Toplam & 244 & 100 \\
\hline
\end{tabular}

Tüketicilerin geleneksel gıda ürünlerinde satın alma davranışları

Tüketicilerin geleneksel gıdaları satın alımlarını etkileyen unsurlar Çizelge 10'da verilmiştir. Elde edilen sonuçlara göre tüketicilerin yarısından fazlası kalite, tat ve aroma, gıda güvenliğii, sağlıklı olması, koruyucu madde içermeme ve son kullanma tarihinin geleneksel gıdaları satın almada etkili olduğunu ifade etmiştir. Bunun yanı sıra fiyat, ambalaj, promosyon, ürünün büyüklüğü ve üretim yerinin tüketici tercihini etkileyen önemli unsurlar değildir. Tüketicilerin geleneksel gıdaları satın almada en çok etkileyen unsurların ise son kullanma tarihi (\%67.70), sağlıklı olması (\%63.80) ve koruyucu madde içermemenin (\%56.20) en çok etkili olduğunu belirtmişlerdir. 
Çizelge 10. Tüketicilerin geleneksel gıdaları satın alımlarını etkileyen unsurlar (gıda ile ilgili)

\begin{tabular}{|c|c|c|c|c|c|c|c|c|}
\hline Unsurlar & & $1 *$ & 2 & 3 & 4 & 5 & Toplam & $\begin{array}{c}\text { Ortala } \\
\text { ma }\end{array}$ \\
\hline \multirow{2}{*}{ Son Kullanma Tarihi } & $\mathrm{n}$ & 8 & 9 & 26 & 81 & 260 & 384 & \multirow{2}{*}{4.50} \\
\hline & $\%$ & 2.10 & 2.30 & 6.80 & 21.10 & 67.70 & 100.00 & \\
\hline \multirow{2}{*}{ Sağlıklı Olması } & $\mathrm{n}$ & 8 & 5 & 25 & 101 & 245 & 384 & \multirow{2}{*}{4.48} \\
\hline & $\%$ & 2.10 & 1.30 & 6.50 & 26.30 & 63.80 & 100.00 & \\
\hline \multirow{2}{*}{ Kalite } & $\mathrm{n}$ & 7 & 6 & 28 & 147 & 196 & 384 & \multirow{2}{*}{4.35} \\
\hline & $\%$ & 1.80 & 1.60 & 7.30 & 38.30 & 51.00 & 100.00 & \\
\hline \multirow{2}{*}{ Gıda Güvenliği } & $\mathrm{n}$ & 11 & 8 & 30 & 129 & 206 & 384 & \multirow{2}{*}{4.33} \\
\hline & $\%$ & 2.90 & 2.10 & 7.80 & 33.60 & 53.60 & 100.00 & \\
\hline \multirow{2}{*}{ Tat ve Aroma } & $\mathrm{n}$ & 8 & 7 & 39 & 135 & 195 & 384 & \multirow{2}{*}{4.31} \\
\hline & $\%$ & 2.10 & 1.80 & 10.20 & 35.20 & 50.80 & 100.00 & \\
\hline \multirow{2}{*}{$\begin{array}{l}\text { Koruyucu Madde } \\
\text { İçermeme }\end{array}$} & $\mathrm{n}$ & 10 & 16 & 52 & 90 & 216 & 384 & \multirow{2}{*}{4.27} \\
\hline & $\%$ & 2.60 & 4.20 & 13.50 & 23.40 & 56.20 & 100.00 & \\
\hline \multirow{2}{*}{ Besin Değeri } & $\mathrm{n}$ & 13 & 22 & 59 & 128 & 162 & 384 & \multirow{2}{*}{4.05} \\
\hline & $\%$ & 3.40 & 5.70 & 15.40 & 33.30 & 42.20 & 100.00 & \\
\hline \multirow{2}{*}{ Satıcının Bilinir Olması } & $\mathrm{n}$ & 18 & 20 & 59 & 158 & 129 & 384 & \multirow{2}{*}{3.94} \\
\hline & $\%$ & 4.70 & 5.20 & 15.40 & 41.10 & 33.60 & 100 & \\
\hline \multirow{2}{*}{ Kolay Temin Etme } & $\mathrm{n}$ & 15 & 27 & 94 & 149 & 99 & 384 & \multirow{2}{*}{3.75} \\
\hline & $\%$ & 3.90 & 7.00 & 24.50 & 38.80 & 25.80 & 100 & \\
\hline \multirow{2}{*}{ Üretici Firma } & $\mathrm{n}$ & 23 & 38 & 79 & 128 & 116 & 384 & \multirow{2}{*}{3.72} \\
\hline & $\%$ & 6.00 & 9.90 & 20.60 & 33.30 & 30.20 & 100.00 & \\
\hline \multirow{2}{*}{ Etiket Bilgileri } & $\mathrm{n}$ & 30 & 38 & 99 & 111 & 106 & 384 & \multirow{2}{*}{3.59} \\
\hline & $\%$ & 7.80 & 9.90 & 25.80 & 28.90 & 27.60 & 100.00 & \\
\hline \multirow{2}{*}{ Tavsiye Edilme } & $\mathrm{n}$ & 20 & 48 & 113 & 125 & 78 & 384 & \multirow{2}{*}{3.50} \\
\hline & $\%$ & 5.20 & 12.50 & 29.40 & 32.50 & 20.30 & 100 & \\
\hline ت̈retim Yeri & $\mathrm{n}$ & 56 & 31 & 99 & 111 & 87 & 384 & \\
\hline Uretım Yerı & $\%$ & 14.60 & 8.10 & 25.80 & 28.90 & 22.70 & 100.00 & 3.37 \\
\hline & $\mathrm{n}$ & 45 & 54 & 98 & 96 & 91 & 384 & \\
\hline Ambalaj & $\%$ & 11.70 & 14.10 & 25.50 & 25.00 & 23.70 & 100.00 & 3.35 \\
\hline & $\mathrm{n}$ & 44 & 57 & 104 & 108 & 71 & 384 & \\
\hline Fiyat & $\%$ & 11.50 & 14.80 & 27.10 & 28.10 & 18.50 & 100.00 & 3.27 \\
\hline & $\mathrm{n}$ & 47 & 64 & 115 & 102 & 56 & 384 & \\
\hline Urün Merakı & $\%$ & 12.20 & 16.70 & 29.90 & 26.60 & 14.60 & 100 & 3.15 \\
\hline Diğer Tüketicilerin & $\mathrm{n}$ & 71 & 88 & 82 & 84 & 59 & 384 & \\
\hline $\begin{array}{l}\text { Taleplerinin Fazla } \\
\text { Olmas1 }\end{array}$ & $\%$ & 18.50 & 22.90 & 21.30 & 21.90 & 15.40 & 100 & 2.93 \\
\hline Dromocyon & $\mathrm{n}$ & 78 & 53 & 84 & 93 & 76 & 384 & 300 \\
\hline Promosyon & $\%$ & 20.30 & 13.80 & 21.90 & 24.20 & 19.80 & 100.00 & 3.09 \\
\hline 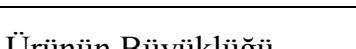 & $\mathrm{n}$ & 94 & 45 & 96 & 72 & 77 & 384 & \\
\hline Urunun Buyuklugu & $\%$ & 24.50 & 11.70 & 25.00 & 18.80 & 20.10 & 100.00 & 2.98 \\
\hline & $\mathrm{n}$ & 93 & 93 & 82 & 75 & 42 & 384 & \\
\hline Reklam & $\%$ & 24.20 & 24.20 & 21.40 & 19.50 & 10.70 & 100 & 2.68 \\
\hline
\end{tabular}

*(1: Etkisiz, 2: Biraz Etkili, 3. Orta Derece Etkili, 4: Oldukça Etkili, 5: Çok Etkili)

\section{SONUÇ}

Türkiye'de tarımsal üretim çeşitliliği, iklim yapısı, coğrafi konum ve kültürel miras geleneksel gıdaların çeşitliliğini artırmaktadır. Tüketicilerin geleneksel gıdaların daha sağlıklı ve doğal olduğu algısının artışıyla bu gıdalara talebin gün geçtikçe arttığı ifade edilmektedir. Bu çalışmada, Mersin ilinde geleneksel gida ürünlerinde tüketicilerin tercihleri, tutumları ve satın alma davranışını etkileyen unsurlar ortaya konulmuştur.

Ankete katılan tüketicilerin yarısından fazlası kadın olup, tüketicilerin yarısı üniversite mezunudur. Tüketicilerin yarıdan fazlası sabit gelirli olup, aylık gelirlerinin \%29'unu gida harcamasına ayırmaktadır. Tüketicilerin çoğunluğu geleneksel gıda ile yöresel gıdaların farklı ürünleri ifade ettiğini düşünmekte 
olup örnek olarak yoğurt, peynir ve salça gibi evde yapılabilen ürünleri söylemektedir. Tüketicilerin yarısından fazlası geleneksel gidaları evde yapabildiğini, bununla beraber yarıya yakını geleneksel ürün satın alma sıklığının ise bazen olduğunu belirtmiştir.

Tüketiciler, geleneksel gıdaları çoğunlukla marketlerden satın aldığını ve satın alma yer tercihinde öncelikli neden olarak güvenilir olması ve satın aldığı yerin evine yakın olması gerektiğini belirtmişlerdir. $\mathrm{Bu}$ durum satın alınan yerinin seçiminde, denetlenebilir olmasından dolayı marketlerin diğer satış birimleriyle karşılaştırıldığında daha güvenilir olmasının önemli olduğunu ortaya koymaktadır. Ayrıca, marketlerin geleneksel gıdalar için raf ve stand ayırmaları geleneksel gidaların bir sektör haline geldiğinin göstergesi olduğu söylenebilir.

Tüketicilerin en çok tercih ettikleri geleneksel gıdalar peynir, yoğurt gibi süt ürünleri olmuştur. Özel günlerde geleneksel gıda tüketiminin arttığ 1 , ayrıca gelirin artmasiyla geleneksel gida tüketiminin de artacağını belirtmişlerdir. $\mathrm{Bu}$ artış oranının tüketicilerin eğitim düzeyi arttıkça azaldığ gözlenmiştir. Tüketiciler, geleneksel gıdaları satın almada en çok etkileyen özelliğin ve geleneksel gidada en önemli unsurun son kullanma tarihi olduğunu belirtmişlerdir. Bunun yanında geleneksel gıdanın sağlıklı olması, kalite ve gıda güvenliği de önemli unsurlar olup, promosyon, ürünün büyüklüğü ve reklam geleneksel gidaları satın almada en az etkili olan unsurlar olmuştur.

Geleneksel gıdaların doğal, lezzetli ve sağlıklı olduğu fikri ön plana çıkmış olup, geleneksel gıdaların daha düşük kalorili ve daha ucuz olduğu fikrine en az oranda katılmışlardır. Tüketicilerin yarısından fazlası paketli ürün almak için daha fazla fiyat ödemeye razı olurken, bu kişilerin çoğunluğu ek bedel olarak fiyatın \%5'ine kadar ödemeyi kabul etmiştir.

\section{KAYNAKLAR}

Aktaş, E. ve Yılmaz, Y., 2012. Mersin'de Ramazan Ayının Gıda Tüketim Harcamaları Üzerine Etkisi. Uludağ Üniv. İktisadi ve İdari Bilimler Fak. Derg., 2 (2012): 177-194.

Almli, V. L., Verbeke, W., Vanhonacker, F., Naes, T. and Hersleth, M., 2011. General Image and Attribute Perceptions of Traditional Food in Six European Countries. Food Quality and Preference, 22 (1): 129-138.

Anonim. 1995. Coğrafi İşaretlerin Korunması Hakkında Kanun Hükmünde Kararname. 27 Haziran 1995 Tarih 22326 Sayılı Resmi Gazete. 75-86. Ankara.

Anonim, 2011. Türk Gıda Kodeksi Yönetmeliği. 29 Aralık 2011 Tarih ve 28157 Sayılı Resmi
Gazete. Necatibey Cad. No: 108 Kat: 4, Bakanlıklar, Ankara.

Anonim, 2013. Türk Gıda Kodeksi Gıda Katkı Maddeleri Yönetmeliği. 30 Haziran 2013 Tarih ve 28693 Sayılı Resmi Gazete. Necatibey Cad. No: 108 Kat: 4, Bakanlıklar, Ankara.

Anonim, 2016. Türkiye İstatistik Kurumu Adrese Kayıtlı Nüfus Sistemi. TÜİK. Ankara. https://biruni.tuik.gov.tr/medas/?kn=95\&locale $=$ tr. $($ Erişim Tarihi: 28.12.2016)

Balogh, P., Bekesi, D., Gorton, M., Popp, J. and Lengyel, P., 2016. Consumer Willingness to Pay for Traditional Food Products. Food Policy, Number 61(2016): 176-184.

Banterle, A. and Gellynck, X., 2008. Perspectives of Traditional Food Supply Chains on the European Market. 12.Congress of the European Association of Agricultural Economists "People, Food and Environments: Global Trends and European Strategies, August 26-29, 2008, Ghent, Belgium.

Başaran, B., 2016. Trabzon'da Yaşayan Tüketicilerin Geleneksel Gıdalara Yönelik Tutum ve Algıları. Gaziosmanpaşa Üniv. Ziraat Fak. Derg., 33 (1): 99-110.

Cerjak, M., Haas, R., Brunner, F. and Tomic, M., 2014. What Motivates Consumers to Buy Traditional Food Products? Evidence from Crotia and Austria Using Word Association and Laddering İnterwiews. British Food Journal, 116 (11): 1726-1747.

Cumhur, Ö., 2017. Geleneksel Gidaların Endüstriyel Üretime Aktarılması. 1.Uluslararası Turizmin Geleceği Kongresi: İnovasyon, Girişimcilik ve Sürdürülebilirlik (Futorism 2017), 28-30 Eylül, 2017, Mersin, Türkiye, Bildiriler Kitab1, s. 396401.

Espejel, J., Fandos, C. and Flavian, C., 2007. The Role of Intsrinsic and Extrinsic Quality Attributes on Consumer Behaviour for Traditional Food Products. Managing Service Quality, 17 (6): 681-701.

Kadanal1, E. ve Dağdemir, V., 2016. Tüketicilerin Yöresel Gıda Ürünleri Satın Alma İstekliliği. Gaziosmanpaşa Üniv. Ziraat Fak. Derg., 33 (1): 9-16.

Karakaş, H. ve Törnük, F., 2016. Geleneksel Gıdaların Okul Çağı Çocuklarının Beslenmesindeki Rolü Üzerine Bir Araştırma. Cumhuriyet Üniv. Fen Fak. Fen Bilimleri Derg., 37 (3): 292-302.

Koç, B., Altun, T.G., Güleç, H.A. ve Baydaş, A., 2012. Geleneksel Gida Ürünleri Tüketim Pazarının Analizi: Van İli Uygulaması. 10.Ulusal Tarım Ekonomisi Kongresi, Konya, Türkiye, Bildiriler Kitab1, s. 909-915. 
Kuşat, N., 2012. Bölgesel Kalkınmada Geleneksel Gıda Ürünlerinin Rolü ve Geleneksel Gıdalarda İnovasyon Belirleyicileri Üzerine Bir Çalışma: Afyon Örneği. Celal Bayar Üniv. İktisadi ve İdari Bilimler Fak. Derg., 19 (2): 261-275.

Malhotra, N.K. 2004. Marketing Research (An Applied Orientation). Pearson Prentice Hill. Fourth Edition. 713 pp.

Onurlubaş, E. ve Taşdan, K., 2017. Geleneksel Ürün Tüketimini Etkileyen Faktörler Üzerine Bir Araştırma. Abant İzzet Baysal Üniv. Sosyal Bilimler Enstitüsü Derg., 17 (17): 115-132.

Oraman, Y., Unakıtan, G., Yılmaz, E. ve Başaran, B. 2011. Analysis of the Factor Affecting Consumer's Some Traditional Food Products Preferences by Multidimensional Scaling Method. Journal of Tekirdağ Agricultural Faculty. 8(1): 33-40.

Örücü, E. ve Tavşancı, S., 2001. Gıda Ürünlerinde Tüketicinin Satın Alma Eğilimini Etkileyen Faktörler ve Ambalajlama. Muğla Üniv. Soysal Bilimler Enstitüsü Derg., (Bahar) Cilt 3: 109122.
Schneider, G.K. ve Ceritoğlu, A.B., 2010. Yöresel Ürün İmajının Tüketici Satınalma Davranışı ve Yüksek Fiyat Ödeme Eğilimi Üzerindeki Etkisi - İstanbul İlinde Bir Uygulama. Pazarlama ve Pazarlama Araştırmaları Derg., 3 (6): 29-52.

Tan, E., 2009. Türkiye Geleneksel Gida Ürünleri Projesi. II. Geleneksel Gidalar Sempozyumu, 27-29 Mayıs, 2009, Van, Türkiye, www.gelenekselgidalar.com/dosyalar2/view.ph p?file=Enver+Tan.pdf. (Erişim Tarihi: 27.10.2017)

Taşdan, K., Albayrak, M., Gürer, B., Özer, O., Albayrak, K. ve Güldal, H.T., 2014. Geleneksel Gıdalarda Tüketicilerin Gıda Güvenliği Algısı: Ankara İli Örneği. In: 2. Uluslararası Davraz Kongresi, 29-31 Mayıs, Isparta, Türkiye, Bildiriler Kitab1, s. 363-386.

Weichselbaum, E., Benelam, B. and Soares Costa, H., 2009. "Traditional foods in Europe", No. FP6 FOOD-CT-2005-513944, EU 6th Framework Food Quality and Safety Thematic Priority. European Food Information Resource (EuroFIR), (Access Date: 30.08.2017) 